\title{
SPECIAL ISSUE ON WILLIAM MORRIS
}

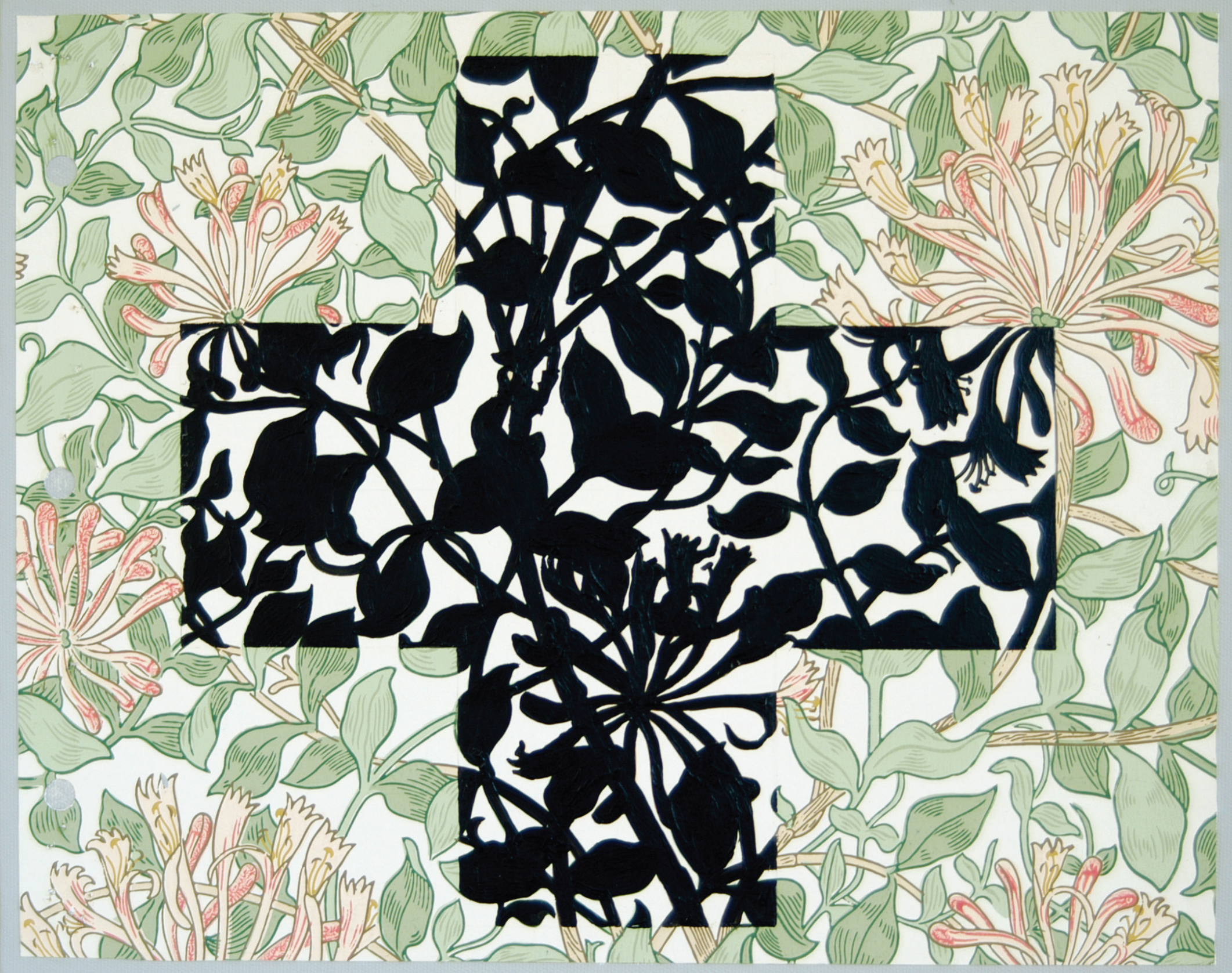


TABLE OF CONTENTS

Special Issue: William Morris

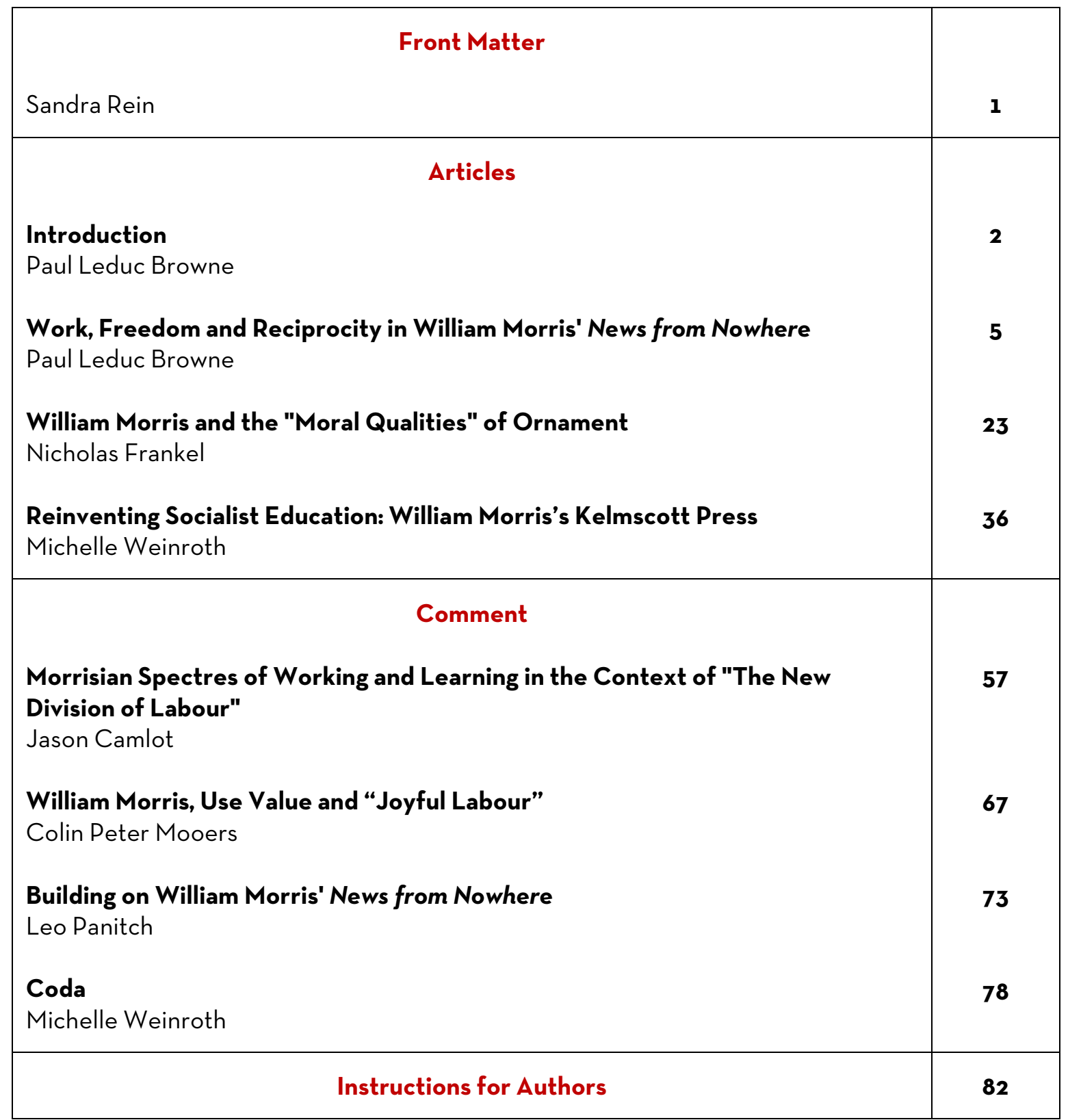


Socialist Studies/Études socialistes is a peer-reviewed, interdisciplinary and open-access journal with a focus on describing and analysing social, economic and/or political injustice, and practices of struggle, transformation, and liberation.

Socialist Studies/Études socialistes is indexed in EBSCO Publishing, Left Index and the Wilson Social Sciences Full Text databases and is a member of the Canadian Association of Learned Journals (CALJ).

Socialist Studies/Études socialistes is published by the Society for Socialist Studies. The Society for Socialist Studies (SSS) is an association of progressive academics, students, activists and members of the general public. Formed in 1966, the Society's purpose is to facilitate and encourage research and analysis with an emphasis on socialist, feminist, ecological, and antiracist points of view. The Society for Socialist Studies is an independent academic association and is not affiliated with any political organization or group. The Society is a member of the Canadian Federation for Humanities and Social Sciences (CFHSS) and meets annually as part of the Congress of the Humanities and Social Sciences.

For further information on the Society for Socialist Studies, please visit www.socialiststudies.ca or contact societyforsocialiststudies@gmail.com.

\section{Issue Cover credit:}

David Mabb. Rhythm 69, painting 32, (William Morris block printed pattern book, with Hans Richter storyboard, developed from Richter's 'Rhythmus 25' and Kazimir Malevich's film script 'Artistic and Scientific Film - Painting and Architectural Concerns - Approaching the New Plastic Architectural System'). Paint and wallpaper on canvas, each canvas 20" x 16", 2004-2007. 
Editor

Sandra Rein, University of Alberta, Canada

editorsocialiststudies@gmail.com

Layout Editor

Sean Cain, Better World Communications

seancain@freelancewrite.org

Proofing \& Copy Edit

Stacey Haugen, University of Alberta, Canada

\section{Editorial Board}

Paul Kellogg, Athabasca University, Canada

Aziz Choudry, McGill University, Canada

Larry Patriquin, Nipissing University, Canada

Patrice LeClerc, St. Lawrence University, United States

Ross A Klein, Memorial University, Canada

Elaine Coburn, Centre d'intervention and d'analyse sociologique (CADIS)-EHESS/American University-Paris, France

Bill Carroll, University of Victoria, Canada 


\section{Front Matter \\ Special Issue on William Morris}

It is with great pleasure that Socialist Studies is able to publish a Special Issue on William Morris under the guest editorship of Dr. Paul Leduc Browne. Paul Leduc Browne (D.Phil., Sussex) is Professor of social and political thought in the Social Sciences Department at the Université du Québec en Outaouais, in Gatineau, Québec. He has published in the fields of political philosophy, social theory, and social policy. He is the author and editor of nine books and special journal issues, including To Build a Shadowy Isle of Bliss: William Morris's Radicalism and the Embodiment of Dreams (McGill-Queen's University Press, 2015) with Michelle Weinroth. It has been a pleasure working with Paul on this Special Issue - not only because of the quality of submissions he has assembled, but also because he brings such a depth of knowledge about Morris and a passion for sharing Morris' insights and works with a new generation of socialist intellectuals.

For those who were influenced by Morris in the past, our hope is that this reengages you with his radical contributions in the context of contemporary capitalist society - perhaps one that in many ways has not changed significantly from Morris' own time. For those who are new to Morris, our hope is that this encourages you to find out more and draw new insights from historical radicalism. 